\title{
Opinions about bedside nursing handover in surgical units: translation, adaptation and validation of questionnaires
}

Opiniōes sobre a visita de enfermagem em unidades de cirurgia: tradução, adaptação e validação de questionários

Opiniones sobre el cambio de turno de enfermeros en unidades quirúrgicas: traducción, adaptación y validación de cuestionarios

Tânia Manuel Moço Morgado*; Lucília Rosa Mateus Nunes**

\begin{abstract}
Background: Although bedside nursing handover ensures the continuity of nursing care, it raises several ethical issues. Objectives: To translate, adapt and validate 2 data collection questionnaires about bedside nursing handover in surgical units into Portuguese, and identify the patients and nurses' opinions about bedside nursing handover.

Methodology: Translation, back-translation and adaptation of the questionnaires in 7 surgical units of a central hospital in Portugal between 22/08/2008 and 28/06/2009. The non-probability sampling consisted of 137 nurses and 96 patients.

Results: Bedside nursing handover promotes an empathic and helping relationship, patient observation and care planning; however, it is necessary to clarify its purpose, encourage patient participation and engagement, use clear information, and ensure information privacy.

Conclusion: The questionnaires proved to be reliable and valid to identify the patients and nurses' opinions about bedside nursing handover in the surgical units under analysis.
\end{abstract}

Keywords: shift work; nursing; visitors to patients; patient-centered care; ethics, nursing

\section{Resumo}

Enquadramento: Apesar da visita de enfermagem ou passagem de turno junto dos doentes garantir a continuidade dos cuidados de enfermagem, origina diversas questões éticas.

Objetivos: Traduzir, adaptar e validar 2 questionários de colheita de dados sobre a visita de enfermagem em unidades cirúrgicas para a cultura portuguesa; identificar a opinião dos doentes e dos enfermeiros sobre a visita de enfermagem.

Metodologia: Tradução, retroversão e adaptação dos questionários aplicados em 7 unidades cirúrgicas de um hospital central em Portugal de 22/08/2008 a 28/06/2009. A amostragem não probabilística acidental foi constituída por 137 enfermeiros e 96 doentes.

Resultados: A visita de enfermagem promove a relação empática e de ajuda; a observação do doente e o planeamento de cuidados, no entanto é necessário clarificar o seu objetivo; incentivar à participação e ao envolvimento dos doentes; utilizar um discurso compreensível e garantir a privacidade da informação.

Conclusão: Os questionários revelaram-se fidedignos e válidos na identificação das opiniões dos doentes e dos enfermeiros sobre a visita de enfermagem nas unidades de cirurgia em estudo.

Palavras-chave: trabalho em turnos; enfermagem; visitas a pacientes; assistência centrada no paciente; ética de enfermagem

\footnotetext{
*MSc., Nurse Specialist in Mental Health and Psychiatric Nursing, Coimbra Hospital and University Center, 3000-075, Coimbra, Portugal [tmorgado@gmail.com]. Address for correspondence: Rua Flávio Rodrigues, n. ${ }^{\circ}$ 59, R/c Dto, 3000-075, Coimbra, Portugal. Contribuição no artigo: literature search, data collection, statistical treatment and analysis, data analysis and discussion, article writing (study resulting from a master's dissertation).

**Ph.D., Nurse Specialist in Mental Health and Psychiatric Nursing, School of Health, Polytechnic Institute of Setúbal, 2914-503 Setúbal, Portugal [lucilia.nunes@ess.ips.pt]. Contribution to the article: Supervisor of the Master's Dissertation; Article revision.
}

\section{Resumen}

Marco contextual: A pesar de que el cambio de turno de enfermeros garantiza la continuidad de los cuidados de enfermería, origina diversas cuestiones éticas.

Objetivos: traducir, adaptar y validar 2 cuestionarios de recogida de datos sobre los cambios de turno de enfermeros en unidades quirúrgicas a la cultura portuguesa; identificar las opiniones de los pacientes y los enfermeros acerca del cambio de turno de los enfermeros.

Metodología: Traducción, retroversión y adaptación de los cuestionarios aplicados en 7 unidades quirúrgicas de un hospital central de Portugal del 22/08/2008 al 28/06/2009. El muestreo no probabilístico accidental constaba de 137 enfermeros y 96 pacientes.

Resultados: El cambio de turno de enfermeros promueve la relación empática y de ayuda; la observación del paciente y la planificación de los cuidados de enfermería, sin embargo, es necesario aclarar su propósito; fomentar la participación y la implicación de los pacientes; utilizar un discurso comprensible, y garantizar la privacidad de la información. Conclusión: Los cuestionarios demostraron ser fiables y válidos para identificar las opiniones de los pacientes y los enfermeros acerca del cambio de turno de enfermeros en las unidades quirúrgicas en estudio.

Palabras clave: trabajo por turnos; enfermería; cambio de turno de enfermeros; atención dirigida al paciente; ética en enfermería

Received for publication: 08.06 .15 Accepted for publication: 09.03 .16 


\section{Introduction}

Bedside nursing handover (BNH), commonly known as bedside change-of-shift reporting, has been a common practice and if, on the one hand, it ensures the continuity of nursing care, on the other hand, it may give rise to ethical issues related to the principle of respect for autonomy and self-determination or for information confidentiality. Patients should be asked about their opinions on $\mathrm{BNH}$ with a view to improving the quality of nursing care. The scarce national scientific evidence on $\mathrm{BNH}$ led to a literature review that allowed identifying the state-of-the-art on this issue. Internationally, we highlight the study conducted by Timonen and Sihvonen (2000) in Finland, which compared the patients and nurses' perspectives on the purpose of $\mathrm{BNH}$, the patient participation and the factors that promote or prevent their participation, through two different questionnaires applied to 118 nurses and 74 patients, with answers from $81 \%$ of the participants in both groups. The authors concluded that the change-of-shift report was merely transferred from the nurses' station to the patient's bedside without any modification, and that nurses should encourage patients to participate, asking them questions and using clear language.

Our study aimed at translating and validating the data collection questionnaires on $\mathrm{BNH}$ in surgical units used by Timonen and Sihvonen (2000) into Portuguese, and identifying the patients and nurses' opinions on BNH in surgical units of a central hospital in Portugal.

\section{Background}

Change-of-shift reporting is the moment when the nursing team meets to ensure the continuity of care and promote the continuous improvement of the quality of care through the analysis of practices and in-service training (Ordem dos Enfermeiros, 2001). This procedure was implemented after World War II in the business context and then extended to all professional contexts, including health care settings, particularly to nursing care (Soares, 2004). Over time, health professionals have become more aware of the need to engage the patient, considering him/her as a member of the multidisciplinary team and promoting his/her participation in every contact, namely during bedside handovers (Teixeira, 2005).

In Coimbra, BNH was first implemented at the end of the 1970s in the Pediatric Hospital, and at the end of the 1980s in the Coimbra University Hospitals (Ferreira, Luzio, \& Santos, 2010; Morgado, 2010). In Portugal, several reflection articles on BNH were published in the beginning of the $21^{\text {st }}$ century (Santos \& Ferreira, 2004; Soares, 2004; Teixeira, 2005; Oliveira, Ferreira, Campos, Pinheiro, \& Azevedo, 2007). However, it seems that there are only two research studies about this practice (Couceiro cited by Morgado, 2010; Ferreira et al., 2010). Couceiro (cited by Morgado, 2010, p.117) developed a qualitative exploratory-descriptive study on BNH with an intentional sample of five nurses and a theoretical sample of nine experts. The author concluded that, although it is considered that the objectives of a change-of-shift reporting do not overlap those of the $\mathrm{BNH}$, that $\mathrm{BNH}$ is seen as a nursing action, without patient engagement, and that it violates the citizen's rights to intimacy, BNH is a privileged space of communication and relationship and an opportune moment for patient participation. In turn, Ferreira et al. (2010) performed a qualitative exploratory-descriptive study with the purpose of describing the patients' views on BNH. The authors used an intentional sample composed of 10 patients undergoing a surgical procedure with a minimum of 7 days of hospital stay in three inpatient surgical units. The results showed that BNH allows for care continuity; mutual nurse-patient knowledge; supervision of the care provided by nurses and students, and respect for the patients' right to information, being necessary to improve the patient interaction and engagement, the use of a clear language, and the respect for their individuality and information confidentiality. According to Opinion CJ-20/2001 of the Ordem dos Enfermeiros (Portuguese Nurses' Association) (2001), the venues where the change-of-shift reporting takes place should be determined in each workplace in the most appropriate way to meet the purposes, and can be used both in exclusive areas for nurses or in each patient's area within the unit. It is also mentions that BNH should ensure the continuity of nursing care, while respecting the patients' right to privacy and information confidentiality, and the health professionals' use of the therapeutic privilege (Ordem dos Enfermeiros, 2001). Internationally, since the end of the 1990s, several studies were published on 
BNH, namely the study conducted by Timonen and Sihvonen (2000) in Finland. More recently, following the accreditation of health organizations by the Joint Commission, several studies were developed for the implementation of projects aimed at improving the quality of BNH (Caruso, 2007; Chapman, 2009; Chaboyer, McMurray, \& Wallis, 2010; Laws \& Amato, 2010).

\section{Research questions}

Can the data collection questionnaires on $\mathrm{BNH}$ in surgical units used in the study of Timonen and Sihvonen (2000) in Finland be used in the Portuguese culture?

What are the patients and nurses' opinions about BNH in surgical units of a central hospital in Portugal?

\section{Methodology}

\section{Type of study}

To accomplish the objectives set out, we developed a methodological study, also called preliminary study, to translate an existing questionnaire and test its translation, through the back-translation or retroversion method (Hill \& Hill, 2005; Fortin, 2009) developed in four phases. Phase 1: Initial translation of the questionnaires from Finnish into English by a Finnish native speaker with proficiency in English. Phase 2: Validation of the translation into English by the authors of the study in Finland. Phase 3: Translation of the English version of the questionnaires validated by the authors of the study conducted in Finland into Portuguese by the researcher and a person with experience in translation and research. Phase 4: Linguistic and conceptual validation of the questionnaires by a panel of three experts in the areas of clinical nursing practice, teaching and research in bioethics, and teaching and research in nursing ethics.

\section{Data collection instruments and variables under analysis}

The questionnaires adapted to the Portuguese reality on the opinions concerning the $\mathrm{BNH}$ in surgical units are different for patients and for nurses. The patients' questionnaire is composed of 36 questions, with eight initial questions for sample characterization. The subsequent questions 9 to 15 address the following topics: sharing the room with other patients; the number of BNH sessions in which the patient has participated; being asked for permission to conduct the $\mathrm{BNH}$; the moment of request for authorization; the description of the discussion between the people involved; and the patient participation in the discussion and reasons for not participating. Questions 16 to 32 include 17 items of BNH-related information which are assessed on a 4-point Likert-type scale. The final questions 33 to 36 address the purpose of $\mathrm{BNH}$ and its benefits for the patients, the patient's perspective on the continuity of $\mathrm{BNH}$, and, finally, the patient's opinion (if any) using an open-ended question format.

The nurses' questionnaire is composed of 43 questions, with six initial questions for sample characterization. The subsequent questions address the following topics: the implementation or not of $\mathrm{BNH}$ in the service where the nurse is currently working and, if it does exist, the weekly frequency with which it is performed; and the request for the patient's authorization or informed consent to conduct the BNH. The $10^{\text {th }}$ question addresses the BNH contents, asking the nurses if these aspects are currently being implemented, and if they think that these should be implemented or not. Questions 11 to 36 include 26 items of BNH-related information which are assessed on a 4-point Likert-type scale, with 17 initial items similar to those in the patients' questionnaire. The final questions address the purpose of the $\mathrm{BNH}$, the characterization of the discussion between the people involved, the patients' participation and lack thereof, identifying the reason; the acquisition and development of knowledge on $\mathrm{BNH}$; the nurse's perspective on the continuity of BNH and, finally, the nurse's opinion (if any) using an open-ended question format.

We conducted a pre-test and applied the questionnaires to three nurses and three patients (who were not included in the sample) so as to analyze the respondents' perception of the clarity, level of understanding and relevance of the questionnaires.

\section{Sample and sampling criteria}

We used a non-probability sample consisting of 96 patients and 137 nurses and calculated sample size based on a minimum number of five subjects per 
analyzed variable or item (Pestana \& Gageiro, 2005; Loureiro \& Gameiro, 2011). Data were collected between 22/08/2008 and 28/06/2009 in a central hospital of Portugal through the application of questionnaires to the patients in two surgical units, and the application of questionnaires to nurses in seven surgical units. The questionnaires were filled out by the nurses themselves when the researcher was absent, while the questionnaires for the patients were filled out by the researcher in the patient's presence. All nurses who belonged to the selected nursing teams and gave their informed consent to participate in the study were included in the sample. Three nurses' questionnaires were excluded for being incomplete. None of the patients' questionnaires was excluded, due to the pre-established inclusion and exclusion criteria. The inclusion criterion was: participation in at least two BNH sessions, or only one at that unit if the patient had already participated in one session in previous hospitalizations at that unit. The exclusion criteria were: patient refusal; reduced visual and auditory acuity; state of confusion or incoherent speech; sensation of pain or malaise; no participation in BNH sessions, or participation in one session without any experience of $\mathrm{BNH}$ from previous hospitalizations.

\section{Formal and ethical procedures}

We initially obtained the informed consent of the Finnish authors to conduct this study in Portugal. All the cultural aspects of the country of origin were taken into account in the process of translation and back-translation of the questionnaires. We selected the experts based on pre-determined criteria and obtained their informed consent. Subsequently, we obtained a favorable opinion from the ethics committee for health, as well as the authorization from the board of directors of the institution where the study was conducted. All the participants gave their informed consent and were ensured of the anonymity of the questionnaires.

\section{Statistical procedures}

After data collection, we elaborated the database using the Statistical Package for the Social Sciences, version 17.0, through which we performed the statistical analysis of the data. The dimensionality of the BNH-related items, scored on 4-point Likert-type scales, was assessed through the principal components analysis with Varimax rotation. Cronbach's alpha coefficient was calculated to assess the internal consistency of the scales and sub-scales. The study of homogeneity was performed through the correlation of each item with the sub-scales and with the subscale if item deleted. Inter-dimension correlations were analyzed using Pearson's correlation coefficients. We also used descriptive statistics to analyze the remaining data and Bardin's content analysis (2008) to analyze the answers to open-ended questions.

\section{Results}

\section{Sample characterization}

The patients' mean age was 57.7 years $(S D=15.9)$, ranging between 18 and 97 years with a coefficient of variation of $27.6 \%$, showing an evident age heterogeneity. In addition, $61.5 \%$ (59) of inpatients were female and $5.2 \%$ (5) could not read or write; 72.9\% (70) had completed basic education; 6.3\% (6) had completed secondary education; 11.5\% (11) had a bachelor's degree or $1^{\text {st }}$ cycle as established in the Bologna process; and 4.2\% (4) had a master's degree or $2^{\text {nd }}$ cycle as established in the Bologna process). Only 6.3\% (6) of the patients had never been hospitalized, and 78.1\% (75) had already been hospitalized several times. The nurses' mean age was 37.4 years $(S D=8.7$ ), ranging between 26 and 55 years and a coefficient of variation of $23.2 \%$, also denoting age heterogeneity. In addition, out of the 137 nurses, 86.1\% (118) were general care nurses; $8.8 \%$ (12) were specialist nurses; and 5.1\% (7) were head nurses. In relation to the professional experience, $73.7 \%$ (101) of the nurses had been working for at least 5 years and, of these, 32.8\% (45) had been working for more than 10 years. All nurses worked at a central hospital considered to be a public enterprise, where $72.3 \%$ (99) had a permanent contract, while $27.7 \%$ (38) had an open-ended contract.

\section{Psychometric equivalence of the questionnaires}

The psychometric characteristics in the Portuguese version of the questionnaires under analysis were determined by assessing their reliability and validity. Reliability refers to the assessment of the consistency of the measurement process (Burns \& Grove, 2009), which corresponds to the homogeneity of the 
statements in a measurement instrument. Cronbach's alpha is the most commonly used technique to estimate the internal consistency of a measurement instrument (Fortin, 2009; Maroco \& Garcia-Marques, 2006); hence we used this technique in this study.

The validity of a measurement instrument demonstrates the extent to which the instrument measures what it should be measuring and corresponds to the degree of accuracy with which the concepts under analysis are represented by the specific statements in a measurement instrument (Burns \& Grove, 2009). With regard to content validity, we used a panel of experts to assess if the content of the scale items accurately measure the variable under analysis (Burns \& Grove, 2009). In relation to the construct or concept validity, we used the method of principal components analysis, which corresponds to a multivariate technique used to reduce the data complexity and the number of variables (Hill \& Hill, 2005).

\section{Nurses' questionnaire}

The dimensionality of the 26 items of the nurses' questionnaire, from questions 11 to 36, was analyzed using the principal components analysis. The initial solution was analyzed so as to identify the number of factors to be retained either through the Cattell's Scree-Test or the Kaiser's criterion. We performed the principal components analysis with Varimax rotation forced to two components, which revealed low loadings of several items and high loadings in both components, leading to the elimination of 10 items. In the last solution, composed of 16 items, we found that the measures of sampling and matrix adequacy allowed continuing the calculations with an adequate level of confidence (Kaiser-MeyerOlkin $=.701$; Bartlett's Sphericity Test, $\chi^{2}$ (136) $=462.875 ; p=.000$ ). Both extracted components explain $33.5 \%$ of the total variance, with $20.6 \%$ for the $1^{\text {st }}$ component and $12.9 \%$ for the $2^{\text {nd }}$ component. Both components had items with factor loadings greater than .45 , which is, according to Tabachnick and Fidell (2007), the cut-off point for a good factor loading. In the first component, the factor loadings ranged between .71 and .45 , whereas in the second component they ranged between .66 and .51. In the $1^{\text {st }}$ component, composed of 11 items, the corrected correlations ranged between .30 and .57 , revealing the inconsistency of item 15 for the construction of the measure. For this reason, the item was deleted, which increased the internal consistency. The analysis of the corrected correlations of the $1^{\text {st }}$ component with the 10 retained items revealed values between 33 and .59, indicating the adequacy of the questions for the development of the measure. Cronbach's alpha was .76, which, according to Peterson (cited by Maroco \& Garcia-Marques, 2006), indicates an appropriate internal consistency. The $1^{\text {st }}$ component, composed of 10 items, was designated as BNH Operationalization. In the $2^{\text {nd }}$ component, the corrected correlations were lower than in the $1^{\text {st }}$ component, ranging between .28 and .45 . However, since excluding item 21 would not increase internal consistency, we decided to keep it. Cronbach's alpha was .60, which Peterson (cited by Maroco \& Garcia-Marques, 2006) believes to be acceptable. The $2^{\text {nd }}$ component, composed of five items, was designated as Nurses' Participation. Subsequently, we correlated both components and found a value of -.114 $(p=.186)$, which showed that the dimensions were independent.

\section{Patients' questionnaire}

The dimensionality of the 17 items of the patients' questionnaire, from questions 16 to 32, was assessed using the same procedures as the nurses' questionnaire. The initial solution was analyzed to identify the number of factors to be retained. The principal components analysis with Varimax rotation forced to two factors resulted in the elimination of items 18 and 32, which showed communalities lower than .25, and of items 16 and 31 for having high factor loadings in two components. The initial solution was composed of 12 items whose measures of sampling adequacy (Kaiser-Meyer-Olkin $=0.633$; Bartlett's Sphericity Test, $\chi 2(78)=394.194, p=.000$ ) enabled us to continue the procedure. The extracted factors explained $37.9 \%$ of the total variance, with $22.3 \%$ corresponding to the $1^{\text {st }}$ component and $15.6 \%$ to the $2^{\text {nd }}$ component. Both components had items with factor loadings greater than .40 , which is a cutoff point below the one recommended for a good factor loading by Tabachnick and Fidell (2007), but above the one indicated as appropriate (.32). In the $1^{\text {st }}$ component, the factor loadings ranged between .81 and .41 , whereas in the $2^{\text {nd }}$ component they ranged between .77 and .48. Subsequently, we performed the psychometric study of the items of each component and their level of internal consistency by reversing 
the scores of the items with negative loadings in the rotated matrix. In the $1^{\text {st }}$ component, composed of 8 items, item 30 revealed low item-total correlations and, for this reason, it was removed, thereby increasing internal consistency. The analysis of the corrected correlations of the $1^{\text {st }}$ component with the seven retained items showed values between .33 and .70 , confirming the adequacy of the questions for the development of the measure. Cronbach's alpha was .72, which is considered by Peterson (cited by Maroco \& Garcia-Marques, 2006) as an appropriate internal consistency. The $1^{\text {st }}$ component, composed of seven items, was designated as Information. In the $2^{\text {nd }}$ component, the corrected correlations were much lower than those of the $1^{\text {st }}$ component, ranging from .34 and .38. As expected, with these values, the value of internal consistency was .57 , i.e. at the threshold of the acceptable value according to Peterson (cited by Maroco \& Garcia-Marques, 2006). The $2^{\text {nd }}$ component, composed of 4 items, was designated as Privacy and Management of Proxemics. Both extracted dimensions showed a Pearson's correlation coefficient of .119 $(p=.249)$, which indicates the independence of the dimensions.

In its final version, the nurses' questionnaire was reduced from 26 to 15 items, integrating two components designated as BNH Operationalization and Nurses' Participation. In turn, the final version of the patients' questionnaire was reduced from 17 to 11 items, also including two components: Information, and Privacy and Management of Proxemics.

\section{Patients and nurses' opinions about BNH}

In relation to its purpose, $59.4 \%$ (57) of the patients considered that $\mathrm{BNH}$ is important to make a brief presentation for nurses and patients; 39.6\% (38) reported that it is important to make a brief presentation for nurses; and only 1\% (1) reported "Don't know". As for the nurses, 48.2\% (66) considered that $\mathrm{BNH}$ is important to make a brief presentation for nurses and patients; $36.5 \%$ (50) reported that it is important to make a brief presentation for nurses; 5.1\% (7) reported that it is important to make a brief presentation for patients; and 10.2\% (14) reported that the BNH has other objectives.

When asked about the benefits of BNH, 83.3\% (80) of the patients considered that they receive more information about the treatment; $80.2 \%$ (77) said that they feel safer with BNH sessions; 37.5\% (36) stated that "I'm still informed today about the care planned for the afternoon and for tomorrow"; and 6.3\% (6) of the patients said that the BNH allows their treatment to be planned in collaboration.

When describing the discussion between those involved in the $\mathrm{BNH}, 96.9 \%$ (93) of the patients considered that "One nurse speaks, the others listen"; 2.1\% (2) considered that "Nurses talk among them"; and only 1\% (1) of them mentioned that "Both nurses and patients participate". In relation to the nurses, $75.2 \%$ (103) of them considered that "One nurse speaks, the others listen"; $19.7 \%$ (27) mentioned that "Both nurses and patients participate"; and only 5.1\% (7) stated that "Nurses talk among them".

Regarding the patient engagement in BNH, 60.4\% (58) of the patients considered that they never participate; $38.5 \%$ (37) considered that they participate sometimes; and only 1\% (1) mentioned that they often participate. The nurses' opinion was different, with 87.6\% (120) indicating that patients sometimes participate; $5.8 \%$ (8) indicated that patients often participate; $5.1 \%$ (7) reported that patients never participate; and only 1.5\% (2) reported that patients always participate.

As regards the reasons for not participating in the $\mathrm{BNH}, 45.8 \%$ (44) of the patients mentioned that "There is not enough encouragement from the nurses"; $4.2 \%$ (4) stated that "The patient is tired"; $1 \%$ (1) indicated that "The BNH is too busy"; and $49 \%$ (47) indicated other reasons. In relation to the nurses' reasons for the lack of patient participation in the BNH, 55.5\% (76) of them reported that "There is not enough encouragement from the nurses"; 13.9\% (19) said that "Patient feels that they cannot ask questions"; $11.7 \%$ (16) said that "The patient is tired"; $2.9 \%$ (4) reported that the "The BNH is too busy"; and 16\% (22) indicated other reasons.

With regard to the continuity of the $\mathrm{BNH}, 84.4 \%$ (81) of the patients mentioned that they would like it to continue to be performed; $8.3 \%$ (8) answered "No" and 7.3\% (7) answered "Don't know". In turn, $46.7 \%$ (64) of the nurses said that they would like it to continue to be performed, $31.3 \%$ (43) answered "No" and 21.8\% (30) answered "Don't know".

In the final question of the questionnaires, patients and nurses were ask to add other remarks on the $\mathrm{BNH}$, which were submitted to content analysis. Based on these opinions, four categories emerged: opinions related to the $\mathrm{BNH}$ operationalization; 
opinions related to information; opinions related to nurses; and opinions related to patients and family. operationalization included six sub-categories for patients and five sub-categories for nurses (Table 1).

The category Opinions related to the $\mathrm{BNH}$

Table 1

Matrix of the category Opinions related to the BNH operationalization

\begin{tabular}{|c|c|c|c|c|}
\hline Sub-Category & $\begin{array}{l}\text { Units of record } \\
\text { (Patients) }\end{array}$ & No. & $\begin{array}{l}\text { Units of Record } \\
\text { (Nurses) }\end{array}$ & No. \\
\hline BNH timing & $\begin{array}{l}\text { It happens too early. [6] } \\
\text { The timing is the best.[2] }\end{array}$ & 8 & $\begin{array}{l}\text { The timing is not appropriate and causes } \\
\text { patients to refuse to participate.[1] }\end{array}$ & 1 \\
\hline BNH duration & $\begin{array}{l}\text { This session should take longer.[6] } \\
\text { There is not much to gain from a 2-minute } \\
\text { session.[1] }\end{array}$ & 7 & $\begin{array}{l}\text { The session should take longer.[2] } \\
\text { The time taken for the handover is not } \\
\text { enough. [1] }\end{array}$ & 3 \\
\hline Number of Nurses & $\begin{array}{l}\text { There should be fewer nurses. [3] } \\
\text { I feel more comfortable with the presence } \\
\text { of only one nurse.[7] }\end{array}$ & 10 & $\begin{array}{l}\text { There should be fewer participants. [3] } \\
\text { Patients feel intimidated by the presence of so } \\
\text { many nurses. }[2]\end{array}$ & 5 \\
\hline BNH purpose & $\begin{array}{l}\text { I am not expected to participate.[28] } \\
\text { The purpose should be explained.[1] } \\
\text { I agree as long as the objectives of the } \\
\text { handover are accomplished.[3] }\end{array}$ & 32 & $\begin{array}{l}\text { The BNH is different from the change-of-shift } \\
\text { reporting. [1] } \\
\text { The patient is unaware of the purpose of the } \\
\text { BNH.[2] }\end{array}$ & 3 \\
\hline $\begin{array}{l}\text { BNH } \\
\text { improvement }\end{array}$ & $\begin{array}{l}\text { It can be divided into two groups. [1] } \\
\text { As long as the objectives of the handover } \\
\text { are accomplished. [3] }\end{array}$ & 4 & $\begin{array}{l}\text { Several aspects can be improved.[1] } \\
\text { To continuously improve this procedure.[1] }\end{array}$ & 2 \\
\hline Noise & Sometimes, there is too much noise.[1] & 1 & & \\
\hline
\end{tabular}

The category Opinions related to information nurses (Table 2).

includes five subcategories for both patients and

Table 2

Matrix of the category Opinions related to information

\begin{tabular}{|c|c|c|c|c|}
\hline Sub-Category & $\begin{array}{l}\text { Units of record } \\
\text { (Patients) }\end{array}$ & No. & $\begin{array}{l}\text { Units of Record } \\
\text { (Nurses) }\end{array}$ & No. \\
\hline $\begin{array}{l}\text { Unclear } \\
\text { information }\end{array}$ & $\begin{array}{l}\text { I don't understand what is said. [34] } \\
\text { The nurses use a very technical language. [2] }\end{array}$ & 36 & $\begin{array}{l}\text { The patient ... doesn't understand. [3] } \\
\text { Adapting the language to be understood by the } \\
\text { patients.[1] }\end{array}$ & 4 \\
\hline $\begin{array}{l}\text { Information } \\
\text { privacy }\end{array}$ & $\begin{array}{l}\text { Issues related to information privacy.[7] } \\
\text { I rather ask my nurse. [5] } \\
\text { I feel that there is no invasion of privacy. [4] }\end{array}$ & 16 & $\begin{array}{l}\text { Lack of information privacy. [8] } \\
\text { Some information that I would not like others } \\
\text { to know about is disclosed. [3] }\end{array}$ & 12 \\
\hline $\begin{array}{l}\text { Sharing of } \\
\text { information }\end{array}$ & $\begin{array}{l}\text { Nurses and patients know each other and } \\
\text { share information. [7] }\end{array}$ & 7 & $\begin{array}{l}\text { If it met the purpose of sharing of information/ } \\
\text { communication between nurse and patient.[1] }\end{array}$ & 1 \\
\hline $\begin{array}{l}\text { Information for } \\
\text { nurses }\end{array}$ & $\begin{array}{l}\text { For nurses to receive information ... [26] } \\
\text { For nurses to be aware of the patient's clinical } \\
\text { status.[2] }\end{array}$ & 28 & $\begin{array}{l}\text { Transmission of information among nurses. [6] } \\
\text { Only for the head nurse or specialists who get } \\
\text { to know the patient.[1] }\end{array}$ & 7 \\
\hline $\begin{array}{l}\text { Information for } \\
\text { patients }\end{array}$ & $\begin{array}{l}\text { The patient is also informed. . . of what is } \\
\text { going to happen. [5] } \\
\text { I am aware of what is being discussed. [2] }\end{array}$ & 7 & The patient receives information. [2] & 2 \\
\hline
\end{tabular}

The category Opinions related to nurses includes (Table 3).

eight sub-categories for both patients and nurses 
Table 3

Matrix of the category Opinions related to nurses

\begin{tabular}{|c|c|c|c|c|}
\hline Sub-Category & $\begin{array}{l}\text { Units of record } \\
\text { (Patients) }\end{array}$ & No. & $\begin{array}{l}\text { Units of Record } \\
\text { (Nurses) }\end{array}$ & No. \\
\hline Informed consent & $\begin{array}{l}\text { They should ask the person for } \\
\text { permission. [2] }\end{array}$ & 2 & $\begin{array}{l}\text { The consent is not ensured. [3] } \\
\text { Patients ... are informed at admission. [1] }\end{array}$ & 4 \\
\hline Nurse presentation & $\begin{array}{l}\text { I would like to meet the nurse who will } \\
\text { care for me. [5] }\end{array}$ & 5 & $\begin{array}{l}\text { It should only be used for the team to introduce } \\
\text { itself to the patient and vice-versa. [2] }\end{array}$ & 2 \\
\hline $\begin{array}{l}\text { Empathic and } \\
\text { helping relationship }\end{array}$ & $\begin{array}{l}\text { It strengthens the relationship with every } \\
\text { nurse.[4] } \\
\text { The nurses care about us. [4] } \\
\text { The nurses are friendly. [6] } \\
\text { The patient feels more supported. . . and } \\
\text { begins to trust the nurses more. [4] } \\
\text { The relationship with the patient takes } \\
\text { place throughout the day. [2] }\end{array}$ & 20 & $\begin{array}{l}\text { There is a stronger relationship between } \\
\text { patients and nurses.[1] Previous interaction in } \\
\text { care.[1] } \\
\text { It functions as an instrument of communication/ } \\
\text { relationship.[2] } \\
\text { It may be improved in order to promote a } \\
\text { better patient/nurse interaction. [1] }\end{array}$ & 5 \\
\hline $\begin{array}{l}\text { Encouragement by } \\
\text { the nurses }\end{array}$ & $\begin{array}{l}\text { The nurses should encourage the } \\
\text { participation of the individual. [5] } \\
\text { If you don't ask, nothing is said. [1] }\end{array}$ & 6 & $\begin{array}{l}\text { The nurses should encourage the active } \\
\text { participation of patients. [6] } \\
\text { The patient should be more engaged.[3] }\end{array}$ & 9 \\
\hline $\begin{array}{l}\text { Overall observation } \\
\text { of the patient and } \\
\text { the ward }\end{array}$ & $\begin{array}{l}\text { They look at the patients and see their } \\
\text { reaction. [1] } \\
\text { For nurses to see the patients. [4] } \\
\text { They look at us.[2] }\end{array}$ & 7 & $\begin{array}{l}\text { It allows for patient observation. [7] } \\
\text { The whole team has a more extensive } \\
\text { knowledge of the patients and the ward.[12] }\end{array}$ & 19 \\
\hline Continuity of care & $\begin{array}{l}\text { To ensure the continuity of care.[1] } \\
\text { They clarify their doubts ... and will } \\
\text { provide better care.[1] }\end{array}$ & 2 & Ensures the continuity of care. [2] & 2 \\
\hline Care planning & $\begin{array}{l}\text { To analyze my situation and take } \\
\text { appropriate measures.[1] } \\
\text { They convey information on what } \\
\text { happened but rarely on what will happen. } \\
\text { [1] }\end{array}$ & 2 & $\begin{array}{l}\text { For the nurse to be able to plan care and } \\
\text { establish priorities. [2] } \\
\text { What is said is not enough for care planning. [1] }\end{array}$ & 3 \\
\hline Quality of care & $\begin{array}{l}\text { To improve the quality of nursing care.[2] } \\
\text { And they will provide better care.[1] }\end{array}$ & 3 & $\begin{array}{l}\text { No contribution to an improvement of the } \\
\text { quality of nursing care. [4] }\end{array}$ & 4 \\
\hline
\end{tabular}

The category Opinions related to patients and family nurses (Table 4). includes five sub-categories for both patients and

Table 4

Matrix of the category Opinions related to patients and family

\begin{tabular}{|c|c|c|c|c|}
\hline Sub-Category & $\begin{array}{l}\text { Units of record } \\
\text { (Patients) }\end{array}$ & No. & $\begin{array}{l}\text { Units of Record } \\
\text { (Nurses) }\end{array}$ & No. \\
\hline Patient refusal & $\begin{array}{l}\text { Because I don't want to. [8] } \\
\text { Afraid to speak out.[2] } \\
\text { I feel no need to talk, I clarified my doubts. } \\
{[12]}\end{array}$ & 22 & $\begin{array}{l}\text { Lack of interest. }[1] \\
\text { The patient felt no need to complement the } \\
\text { information being conveyed. [4] }\end{array}$ & 5 \\
\hline $\begin{array}{l}\text { Patient overall } \\
\text { status }\end{array}$ & $\begin{array}{l}\text { The patient is in pain. [3] } \\
\text { Had no strengths to ask.[1] }\end{array}$ & 4 & $\begin{array}{l}\text { The patient's clinical status. [4] } \\
\text { Altered state of consciousness. [8] }\end{array}$ & 12 \\
\hline $\begin{array}{l}\text { Patient } \\
\text { participation }\end{array}$ & $\begin{array}{l}\text { Opportunity for the patient to ask } \\
\text { questions.[2] } \\
\text { Issues related to patient participation. [1] }\end{array}$ & 3 & $\begin{array}{l}\text { Allows the patient to participate. [1] } \\
\text { Listen to the patient's complaints.[1] } \\
\text { The nurse should promote patient } \\
\text { participation.[9] }\end{array}$ & 11 \\
\hline $\begin{array}{l}\text { Family } \\
\text { participation }\end{array}$ & $\begin{array}{l}\text { I would like my family to be present.[2] } \\
\text { I wouldn't like my relatives to be present.[1] }\end{array}$ & 3 & $\begin{array}{l}\text { The patient and the family don't understand } \\
\text { the language.[1] }\end{array}$ & 1 \\
\hline
\end{tabular}




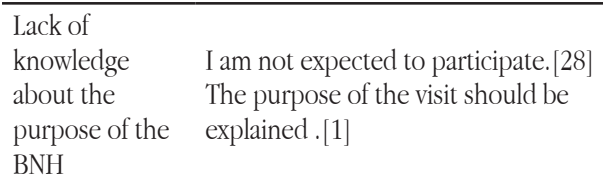

\section{Discussion}

This study had the following limitations: lack of knowledge about the reliability and validity of the original questionnaires and the effect of social desirability, despite the use of techniques to mitigate this effect, namely the completion of the questionnaires by the researcher in the presence of the patients. The use of the 4-point Likert scale, without a central point, on the one hand, minimizes the effect of social desirability, and, on the other hand, provides a greater data concentration. Despite these limitations, the translation, back-translation and adaptation of the questionnaires into Portuguese showed linguistic, conceptual and psychometric equivalence.

The results are consistent with those of other studies conducted in Portugal and in other countries. The study of Couceiro, cited by Morgado (2010), showed that, despite the BNH being a privileged space of communication, relationship and patient engagement, this was not the case and the right to one's intimacy and privacy was even violated. Ferreira et al. (2010) pointed out in their study that, although the BNH allowed for the continuity of care, the mutual knowledge between nurse and patient and the fulfilment of the right to information, there was a need for greater patient interaction and engagement, respect for information confidentiality and use of clear language.

In our study, we considered the BNH to be a moment of: promotion of the empathetic and helping relationship; patient observation; planning of care; and improvement of the quality of nursing care. However, both nurses and patients considered that the lack of patient participation in the BNH is a result of lack of knowledge about its purpose and lack of encouragement from nurses. The participants reported that this procedure is used for nurses to exchange information between them, using an incomprehensible language and putting information privacy in risk.

Some of these results are consistent with those of Timonen and Sihvonen (2000), namely the lack of
29 Lack of knowledge of the patient about the purpose of the BNH.[2] encouragement and the difficulty in understanding the language. However, they differ in the main reason identified in our study for the patients' non-participation in the BNH: tiredness. Another relevant aspect in both studies was the fact that the time of the BNH session was too short. Caruso (2007) developed an innovative study for the implementation of team communication techniques which allowed informing the patients about their role, guiding their participation and minimizing the disclosure of irrelevant information during the BNH. Chapman (2009) developed a similar study which led patients to participate in the BNH sessions by exchanging information with the nurses. Chaboyer et al. (2010) also implemented a project to improve the quality of the $\mathrm{BNH}$, which resulted in an improvement of the accuracy of communication and the promotion of patient-centered care. In the study of Laws and Amato (2010), most nurses considered that the BNH promoted patient participation and safety via direct visualization, allowing for a better planning of the nursing interventions with discussion of the healthcare plan with the patients. In this study, we found that most patients, unlike nurses, would like the BNH to continue to be performed.

\section{Conclusion}

The translation, back-translation and adaptation of the questionnaires into Portuguese showed linguistic, conceptual and psychometric equivalence. The questionnaires proved to be reliable and valid to identify the patients and nurses' opinions about the BNH in the analyzed surgical units. The results emphasized the role of the BNH as an opportunity for promoting an empathetic and helping relationship, while allowing for patient observation, care planning and improvement of the quality of nursing care. This study also indicates the need to clarify the purpose of the BNH at patient admission; encourage patient participation and engagement; use a clear language; and ensure information privacy. The 
identification of new contributions regarding the nurses and inpatients' opinions about the $\mathrm{BNH}$ through these questionnaires is the main implication of this study for practice and research. Quantitative, qualitative or mixed studies should be conducted to contribute to the validation of the questionnaires, and to systematically assess the patients and nurses' satisfaction regarding the BNH. These studies should also focus on the elaboration and implementation of best practices in order to promote the continuous improvement of an increasingly safer and patientcentered BNH.

\section{References}

Bardin, L. (2008). Análise de conteúdo. Lisboa, Portugal: Edições 70.

Burns, N. \& Grove, S. (2009). The Practice of Nursing Research: Appraisal, synthesis and generation of evidence ( $\left.6^{\mathrm{a}} \mathrm{ed}.\right)$. Missouri, United States of America: Saunders.

Caruso, E. (2007). The evolution of nurse-to-nurse bedside report on a medical-surgical cardiology unit. Medsurg Nursing, 16(1), 17-22.

Chaboyer, W., McMurray, A. \& Wallis, M. (2010). Bedside nursing handover: a case study. International Journal of Nursing Practice, 16(1), 27-34.

Chapman, K. (2009). Improving communication among nurses, patients and physicians. American Journal of Nursing, 109(11), 21-25.

Ferreira, R., Luzio, F. \& Santos, M. (2010). Passagem de turno dos enfermeiros nos quartos (Visita de Enfermagem): opinião dos utentes. Revista de Enfermagem Referência, 2(12), 2937.

Fortin, M. F. (2009). Fundamentos e Etapas no Processo de Investigação. Lisboa, Portugal: Lusodidacta.

Hill, M. \& Hill, A. (2005). Investigação por questionário (2a ed.). Lisboa, Portugal: Edições Sílabo.
Laws, D. \& Amato, S. (2010). Incorporating bedside reporting into change-of-shift report. Rebabilitation Nursing, 35(2), 70-74.

Loureiro, L. \& Gameiro, M. (2011). Interpretação crítica dos resultados estatísticos: para lá da significância estatística. Revista de Enfermagem Referência, 3(3), 151-162.

Maroco, J. \& Garcia-Marques, T. (2006). Qual a fiabilidade do alfa de Cronbach? Questões antigas e soluções modernas? Laboratório de Psicologia, 4(1), 65-90.

Morgado, T. (2010). Visita de Enfermagem: Análise em enquadramento bioético - Tradução, adaptação e contributo para a validação transcultural de instrumentos de medida (Master's Thesis). Faculdade de Medicina da Universidade do Porto, Portugal.

Oliveira, A., Ferreira, F., Campos, J. Pinheiro, P. \& Azevedo, P. (2007). Qualidade da informação transmitida na passagem de turno em enfermagem. Revista Nursing, 17(223), 20-23.

Ordem dos Enfermeiros. Conselho Jurisdicional (2001). Parecer CJ-20/2001: Passagem de turno junto aos doentes, nas enfermarias. Lisboa, Portugal: Autor.

Pestana, M., \& Gageiro, J. (2005). Análise de dados para ciências sociais. A complementaridade do SPSS ( $4^{\mathrm{a}}$ ed). Lisboa, Portugal: Sílabo.

Santos, M. \& Ferreira, R. (2004). Passagem de turno junto dos utentes: melhoria efectiva na prestação de cuidados? Revista de Enfermagem Referência, 1(12), 49-53.

Soares, C. (2004). A reunião de passagem de turno: Contributos para uma reflexão. Revista Investigação em Enfermagem, 1(9), 14-23.

Tabachnick, B. \& Fidell, L. (2007). Using multivariate statistics (5 ed.). Boston, United States of America: Pearson/Allyn \& Bacon.

Teixeira, M. (2005). Questões bioéticas: Passagem de turno junto aos doentes. Revista Nursing, 16(201), 27-31.

Timonen, L. \& Sihvonen, M. (2000). Patient participation in bedside reporting on surgical wards. Journal of Clinical Nursing, 9(4), 542-548. 

